\title{
The Alternative Concepts of Blasphemy Law in Indonesia: Legal Comparison with Ireland and Canada
}

\author{
Loresta Cahyaning Lintang $^{\mathrm{a}, 1, *}$, Adriano Martufi ${ }^{\mathrm{a}, 2}$, J.W. Ouwerker ${ }^{\mathrm{a}, 3}$ \\ ${ }^{a}$ Institute of Criminal Law \& Criminology Faculty of Law, Universiteit Leiden, Netherlands \\ ${ }^{1}$ lorestalintang@law.leidenuniv.nl *, 22a.martufi@law.leidenuniv.nl, ${ }^{3}$ J.W.Ouwerkerk@uvt.nl \\ * corresponding author
}

\section{ARTICLE INFO}

Article history

Received: January 15, 2021

Revised: June 25, 2021

Accepted: July 15, 2021

Keywords

Blasphemy;

Indonesia;

Ireland;

Canada;

Comparative;

\section{ABSTRACT}

Indonesia has recognized and implemented blasphemy law within its legal system. Nevertheless, by many scholars, it is considered ambiguous and "no perimeter", which leads to the question of its legal certainty. Blasphemy is different across religions and legal systems, particularly in Ireland and Canada. This study seeks to examine how Indonesia, Ireland, and Canada rule blasphemy. To analyze information about the regulation of blasphemy in those countries, a comparative legal approach is utilized. The result of this study shows that blasphemy laws are heterogeneously written by the national legislation of Indonesia, Ireland, and Canada. Irish blasphemy law includes the element of mens rea, protect all religions in the country. Irish government clearly defines blasphemy law as a limitation of the freedom of expression. Canada does not regulate its blasphemy law strictly but use precedents to maintain the certainty and predictability. Mirroring to these two countries, Indonesian blasphemy law should be reconstructed into five ways: expanding the protected religions to include the minority religions, defining explicit limitations, specifying mens rea element, measuring the 'threat to public' elements, and more professional law enforcement officers.

Q

\section{Introduction}

Later, Joshua was reported to the police for blasphemy against Islam as he allegedly insults the religion. According to the Indonesia Forum of United Muslims (FUIB) which reported the case, his statements offended Muslims lately, Sukmawati Soekarnoputri, a politician and the daughter of Soekarno Indonesia's founding father, created religious turmoil after reading her poem titled 'Ibu Indonesia' (Mother Indonesia) (Rehman \& Shahid, 2018). The poem triggered the Islamic group to report her to the police for alleged blasphemy. In her poem, she declared that the konde (the traditional Indonesian bun) is more beautiful than the niqab and the Indonesian ballad is more melodious than the adzan (the Islamic praying call). Previously, in May 2017, Jakarta's former governor, Basuki Tjahaja Purnama, better known as Ahok, was sentenced to two years imprisonment for blasphemy against Islam. He was found guilty after referring to a verse from the Qur'an during his campaign. He told the voters not to be misled by any religious leaders who use that verse, to make a justification that Muslims should not have non-Muslims leaders (J. Fenton, 2016).

Since Indonesian blasphemy law was written in 1965, according to the Indonesian Human Rights Watch, there have been more than 200 blasphemy cases, including the latest blasphemy case of 
Jakarta's governor. Of those cases, there was only one case in which the suspect was acquitted (Hasan, 2017). Indeed, the Constitution of Republic Indonesia guarantees its citizens freedom of religion and freedom of speech. Apart from that, it is also the task of the government to maintain peace and protect these freedoms from any disturbances. Thus, exercising blasphemy law is the response from the government to maintain and protect the peace and these freedoms in the society (Hasan, 2017).

In practice, Indonesian blasphemy law allows anyone, based on their religion, to report others for anything they subjectively consider a blasphemous act. Therefore, regulation about blasphemy is an ambiguous law where the burden of proof is upon the person or organization who feel offended by it. It means there is a low probability of the suspect being acquitted from the blasphemy case. Indeed, the condition of blasphemy law in Indonesia has 'no perimeter' condition and 'not clearly defined'. As a result, it can lead to legal uncertainty that may jeopardize the individuals (Faiz, 2016).

Blasphemy is often considered to be common only in Muslim-majority countries. However, this statement is not entirely correct. Blasphemy is also applicable in some western countries. Similarly, in Ireland, British Comedian, Stephen Fry was also investigated by the Irish police for alleged blasphemy after his comment about God during an interview in 2015. However, Gardaí Irish police decided not to proceed with the investigation further as they could not find a significant number of people outraged by Fry's statement. Likewise, Canada also has a blasphemy law. The most recent attempt to apply blasphemy law in Canada was in January 2007, when the members of a Christian organization wanted to report the producer of a show that featured a blasphemous libel, but the magistrates and the High Court refused because it did not fulfil the elements of blasphemous libel. Accordingly, blasphemy still exists not only in Muslim-majority countries but also in other nonMuslim majority states (Sholehudin, 2020).

Undeniably, blasphemy is still a debatable topic around the world. On the one hand, from the perspective of those who support its criminalization, blasphemy law is necessary to protect individuals, religions, or any sacred individuals or objects from anything considered disrespectful (Eskin et al., 2020). In addition, blasphemy law is needed to prevent people from insulting or defaming any religion, god, or any other sacred religious thing. On the other hand, those who oppose the blasphemy law say that it infringes upon some fundamental human rights, such as freedom of opinion, freedom of expression and freedom of religion. The fact that there is still no consensus regarding the definition of blasphemy leads to endless debate over this topic (Crouch, 2012).

Theoretically, blasphemy can be passive or active. Passive blasphemy is mainly found in the medieval era, which focuses on encountering blasphemy that threatens peace and social order (Winter et al., 2016). Meanwhile, in the modern period, blasphemy has changed into active blasphemy which focuses on religious sensibility or individual believers who are offended by blasphemous acts or expressions. The definition of blasphemy may differ in other religions and legal systems. Therefore, this research will focus on the definition of blasphemy as a religious concept and a legal concept by Jeremy Patrick. Blasphemy may be different across religions and legal systems (Philip \& Soumyaja, 2019). However, in general, blasphemy is related to improper acts or expressions towards something which is sacred. A precise definition is necessary for the law to have legal certainty. With a precise definition, including what the rules are and what kind of acts are forbidden, a law can be understandable and therefore predictable. Thus, people may know what exactly to do and what exactly not to do. On the other hand, without legal certainty, a law can be vulnerable to be misused and arbitrarily enforced (Tømte, 2012). However, legal certainty does not mean that a law cannot be amended a law still can be changed in line with the current society (Sineath et al., 2016).

The present research explores the future implementation of blasphemy law in Indonesia. New and more precise regulation is needed to replace the current ambiguous blasphemy law. This research aims to suggest alternative concepts of blasphemy law in Indonesia. More specifically, this study addresses the clarity of blasphemy legislation against the background of the principle of legal certainty. Therefore, the present study seeks to answer the following question: "How should Indonesia implement its blasphemy law from the point of view of legal certainty in comparison with Ireland and Canada"

To answer the research question, a comparative analysis of blasphemy law in Indonesia, Ireland, and Canada is conducted. The comparative research is chosen to outline different policy options from different countries that may or may not be implemented in Indonesia. This research, including the 
introduction, theoretical frameworks, and methodology, will consist of six chapters. The theoretical frameworks chapter will explain the concept of legal certainty and blasphemy. Then, the methodology section will show how to answer the research question. The fourth chapter will describe the blasphemy law in Indonesia. Overview of blasphemy law in Ireland and Canada will be presented in chapter five. Lastly, chapter six will be the conclusion of this research and discussion, including some limitations and suggestions for future research.

Some previous studies have been done to evaluate blasphemy law in one specific country. Comparative studies regarding blasphemy law have been studied in several domains. Adam (Tyson, 2021) studied comparative blasphemy law in the realm of religion and state relationships in the Muslim majority countries, Pakistan, Indonesia, and Turkey. Priestley Cox (2019) compared blasphemy law in general between the United States, Germany, Pakistan, the United Kingdom, and Australia. Also, a comparative study by Datar examined whether blasphemy law was legitimate in international law, the European Court of Human Rights, and India. No studies have been done within the scope of the legal certainty principle of the blasphemy law. Therefore, the present study will be beneficial to broaden the knowledge regarding the importance of legal certainty, in particular, when defining crimes in the national legal system. In this way, abuse of power by the government can be eliminated (Cox, 2019).

Furthermore, this research will be beneficial for policymakers. By conducting comparative research in the field of blasphemy law, policymakers can gain a broader knowledge of blasphemy law in other countries and decide how blasphemy law in their country should be implemented. The results of this research may also be of interest to the general public, raising awareness among individuals of the criticism of blasphemy (Eskin et al., 2020). Knowing that the excesses of freedom of speech on religious issues can hamper a situation, the general population and individuals will clearly understand the implications of the issues underlined in this research. From the standpoint of a law enforcement agent, this research may also be relevant. The burden of proof in blasphemy cases is on the person or group of people who reported the case to the police. Therefore, this research can potentially clarify the perimeter condition of blasphemy to law enforcement agents to prevent the arbitrariness and unfairness of blasphemy accusations.

\section{Research Method}

This research examined whether, how, and under what conditions Indonesia, Ireland, and Canada have criminalized blasphemy. Thus, such alternatives from Ireland and Canada may also be implemented into the Indonesian legal order. Comparative legal research was used to answer these research questions. Comparative law is known for its contribution to improving the quality of national law (Moeis et al., 2020). Quality improvement for law can occur by finding new ideas from other jurisdictions. Comparative legal research is chosen in order to be able to perceive more information about the regulation of blasphemy in countries other than Indonesia. Thus, the result of the comparisons could be transferred to the Indonesian legal order (Singh \& McKleroy, 2011).

The primary and secondary data was collected by doing library research. The former included the official English translation of the criminal codes and/or any laws regarding blasphemy, research reports, and government documents such as the Indonesian Criminal Code, Presidential Decree No. 1/PNPS/1965, the Irish Constitution, Irish Defamation Act of 2009, and the Canadian Criminal Code. Meanwhile, the secondary data included all relevant information regarding blasphemy in general, Indonesia, Ireland, and Canada, such as news articles and scholarly studies such as books, journals, articles, and reviews. Also, case laws regarding blasphemy in Indonesia, Ireland, and Canada were collected. The Ministry of Justice's websites, Web of Science, Leiden University Online Library's search tool, and Google Scholar were used to look for relevant data. The websites of the Ministry of Justice of Indonesia, Ireland, and Canada were accessed in order to obtain the official English translation of any regulation regarding blasphemy law. Web of Science was used due to the range of collections of several subjects that were useful for the search process (Tømte, 2012).

Meanwhile, the search tool of Leiden University's online library was used as it had an extensive scope of studies and consisted of several online scientific databases. Google Scholar was used due to the convenient access to the author, the readers, and the future researchers. In finding the relevant literature for this research, several combinations of keywords were used. The keywords that the author 
used were the main topic in this research, such as blasphemy, defamation of religion, blasphemy law in Indonesia, defamation of religion in Indonesia, blasphemy law in Ireland, defamation of religion in Ireland, blasphemy law in Canada, defamation of religion in Canada, the principle of legality, lex and legal certainty. After the relevant data were gathered, they were analyzed, reviewed, and compared to answer the research question and the sub research questions one by one. Firstly, the concept of legal certainty from any relevant studies was assessed. Then, the regulation regarding blasphemy in those three countries was assessed. Further, they were assessed. After that, related data regarding blasphemy law in Indonesia, Ireland, and Canada were examined separately. Lastly, all the relevant data regarding the concept of blasphemy from Ireland and Canada were compared to the Indonesian blasphemy law (Eskin et al., 2020).

\section{Results and Discussion}

\subsection{Freedom of Religion and Expression in Indonesia}

Indonesia is a democratic country which guarantees freedom of expression in its constitution. Under Article 28 of the Indonesian Constitution, "the liberties of association and assembly, the freedom of thought expressed verbally or in writing and similar rights are to be determined by law". Indonesia is also the state party of the ICCPR which guarantees freedom of expression without any limitations except for public order. However, according to the Decision of the Indonesian Constitutional Court No. 140/PUU-VII/2009 on 19th April 2010 on the Judicial Review of the Law number 1/PNPS/1965, religious values can justify the limitation of human rights if it is about the freedom of expression, thought, conscience, and religion. The Constitutional Court stated that forbidding the publication of different interpretations of religions in Indonesia can be a preventive action for any religious conflict among people (Eskin et al., 2020).

Indonesia is not a secular state nor a state based on one religion. It is a multi-religious country which builds upon the principles of 'Belief in Almighty God,' which is mentioned in the preamble of the Indonesian Constitution where everything should be sacralized or grounded with the respect of God (Marshall, 2018). According to the Indonesian Constitution, it has been stated in Article 29 (1) that Indonesia is based on the belief in the One and Only God. Furthermore, Indonesia also guarantees the freedom of religion under Article 29 (2) of its Constitution. The article lays down that "the state guarantees each and every citizen the freedom of religion and worship in accordance with this religion and belief". Moreover, Article 28E (1) of the Constitution states that religious freedom is one of the fundamental human rights, "Every person shall be free to choose and to practice the religion of his/her choice"

Interestingly, Indonesia is a multicultural country. There are about 300 ethnic groups who live in Indonesia with many 'local beliefs'. This means that, according to freedom of religion and freedom of expression enshrined in the constitution, people have a right to choose and practice any religions or beliefs of their choice and also express their speech or understanding about their religion (Necula, 2014). Officially, Indonesia only recognizes six religions: Islam, Protestantism, Catholicism, Buddhism, Hinduism, and Confucianism. However, by only recognizing these religions, it does not mean that any other religions or beliefs will be banned, but, as long as these other religions or beliefs do not disturb the community, they are also free to practice their religions or beliefs (Saud, 2020). Indonesian Constitution guarantees that human rights (including freedom of religion and freedom of expression) should be respected. Furthermore, Article $28(\mathrm{~J})$ of the Indonesian Constitution states the limitation of the application of this right. The Constitution requires every person to accept any restrictions established by law for the purpose of guaranteeing and respecting others' freedoms and rights (Rosidah, 2020).

Also, to protect morality, religious values, security, and public order in a democratic society. Therefore, according to these articles, Indonesia's freedom of religion and freedom of expression are not absolute. The government agreed to restrict these freedoms with laws to prevent any problems concerning morality, public order, and security. One of these laws restricting these freedoms is the blasphemy law. Blasphemy law is essential to protect the recognizesed religions from any blasphemous act, teaching, or expression. Blasphemy law aims to secure the state and society and guarantees that the believers can perform their practices peacefully. Accordingly, blasphemy law 
becomes a justification for charging someone whose actions and expressions insults and blasphemes the religion (J. Fenton, 2016).

In January 1965, President Sukarno - the first president of Indonesia-regulated the Presidential Decree Number 1/PNPS/1965 on the Prevention of Religious Abuse and/or Defamation. In 1969, after the presidential replacement, this Presidential Decree became law and then it was called Law Number 1/PNPS/1965 on Blasphemy Law. The primary reason for which blasphemy law was passed in 1965 was based on the socio-cultural condition of the Indonesian public at that time (Faiz, 2016). Generally, blasphemy law was passed to avoid communism which was emerging during that time. In addition, the law was concerned with prohibiting the emergence of any mystical indigenous belief organizations (aliran kebatinan) which were believed to be the opposite of the religious law and misused the religions so that they could endanger the 'official' religions (Crouch, 2012). Overall, blasphemy law aims to maintain the sanctity of each religion and avoid any deviation and defamation of the official religions because religions cannot defend themselves. Also, it aims to protect religious harmony and maintain public order (Cox, 2020).

The blasphemy law consists of two types of acts, thus requiring different legal procedures to trigger a prosecution. The first one is deviation (penyimpangan) from the official religions (Article 1) and the second one is defamation (penodaan) of the religions (Article 4). According to the law, individuals can be prosecuted if they breach the administrative warning for the religious deviation as stated in Article 1. If these people still breach the warning, they can be prosecuted and if convicted, can be penalized with up to five years imprisonment. On the other hand, unlike the offence of religious deviation under Article 1, the offence of religious defamation does not need the prior administrative warning for the individuals to be prosecuted (Rehman \& Shahid, 2018).

The prohibition of religious defamation is regulated under Article 4 with the maximum penalty of five years imprisonment. This article specifically mandates that the provision will be added to the Indonesian Criminal Code. Then, in 1969, this article is integrated as article 156 (a) of the Indonesian Criminal Code, the current legal basis of blasphemy law as defamation of religion concept in Indonesia which has led to the prosecution of many people who are allegedly defaming religion. However, until today, there has not been any new regulation which amends or removes the blasphemy law. Therefore, this law still exists (Hasan, 2017).

Blasphemy is regulated under Chapter V of the Indonesian Criminal Code on 'Crimes Against the Public Order'. Specifically, blasphemy and defamation of religion are regulated under two articles, Article 156 and Article 156 (a) of the Indonesian Criminal Code. Article 156 has been in the Indonesian Criminal Code since the beginning to prohibit people from publicly expressing hatred or defaming others by race, country of origin, religion, origin, descent, nationality or constitutional condition. Meanwhile, Article 156 (a) is an added article mandated by Article 4 of the blasphemy law (Doomen, 2021).

As seen above, Article 156 is mostly prohibits hate speech based on race, country of origin, religion, origin, descent, nationality or constitutional condition (Tømte, 2012). Meanwhile, Article 156 (a) regulates blasphemy, both regarding deviation or defamation. Based on Article 156 (a), there are four actions that can be labelled as blasphemy if done in public, which are expressing feelings or committing an act having the character of enmity with a religion, expressing feelings or committing an act which abuses a religion adhered to in Indonesia, expressing feelings or committing an act of blasphemy of a religion adhered to in Indonesia, and an act which was done with the intention to prevent a person from adhering to any religion based on the belief in the almighty God.

This shows the three elements of blasphemy that should be fulfilled in order to have a successful prosecution. The first element is 'in public'. The blasphemy has to be done in public or can be heard or seen publicly. This may cause further questions surrounding what the definition and scope of 'in public' can be. Secondly, is 'give expression to feelings or commits an act that has the character of being at enmity with, abusing or staining a religion'. The third element is 'religion, adhered to in Indonesia'. Religion here generally means the six official religions. Further explanation of these elements is left to the judges to interpret (Fuad, 2019). The scope of this article can be found in the Elucidation of Law Number 1/PNPS/1965 on Blasphemy Law. It explains that the offence is in essence with the intent to blaspheme or defame the religion. Therefore, any written and oral expressions about religions which are done objectively and academically with the effort to avoid the 
use of any abusive words should be excluded from this offence. Indeed this explanation is still too broad, but it may become a mitigating effect of blasphemy law's ambiguousness. However, even though the scope of blasphemy has been explained, there are no explicit exceptions of blasphemy in Indonesia (Bourchier, 2019).

Frequently, individuals who are charged with blasphemy, especially on social media, will also be charged with article 28 (2) of the Law Number 11/2008 on Electronic Information and Transaction (ITE law). This is seen with the use of the word 'juncto' in conjunction with while prosecuting someone with blasphemy on social media. Article 28 (2) references the prohibition of disseminating information on social media aimed to inflict hatred based on religion. Article 45 (2) regulates the penalty for people who violate article 28 (2) who can be imprisoned for a maximum of 6 (six) years and/or given a fine not exceeding Rp 1,000,000,000, (one billion rupiah). Indeed, this article does not directly address the crime of blasphemy. However, in practice, this article is often used because of the digitalization era where blasphemy now may also occur in cyberspace (Richardson et al., 2020).

\subsection{Notable Cases of Blasphemy in Indonesia}

As stated before, since the blasphemy law was first enacted, there have been more than 200 cases of blasphemy in Indonesia. The cases vary from the deviation of religion and defamation of religion. Below are the notable cases of blasphemy in Indonesia, both regarding deviation and defamation of religion (Bourchier, 2019).

In 1990, Arswendo Atmowiloto was the editor in chief of a tabloid called Monitor. In each edition, Monitor conducted a questionnaire for the readers. In one questionnaire, it was asked, "Who are the people you admire the most and what is the reason for your vote?". The editor, at this time Arswendo, compiled the results of the questionnaires. The results showed that Soeharto the president at that time had the highest score. Arswendo himself ranked 10th from the vote (Dutta et al., 2019). Meanwhile, Prophet Muhammad was $11^{\text {th }}$ among 50 names. This created protests among Muslims. They felt that the results implied that Arswendo and nine other people in the list above Prophet Muhammad were considered better than the Prophet, thereby insulting Islam (Rehman \& Shahid, 2018). Arswendo was then taken to trial and accused of blasphemy. In his defense, Arswendo declared that he did not have any intention to insult Prophet Muhammad by the polling (Castillo-Manzano et al., 2019). He further stated that he did not know whether comparing Prophet Muhammad may be considered blasphemy by other people. Thus, the element of mens rea or the intent to do blasphemy was not satisfied (De Clercq et al., 2017).

However, Article 156 (a) was not sufficiently clear as regards the requirement of mens rea. As a result, the judges did not take into account this element. Therefore, Arswendo was still convicted of violating Article 156 (a) of the Indonesian Criminal Code because his act was considered as an insult against Islam in the public press, and he was sentenced to four years 6 six months imprisonment (Tyson, 2021).

In 1995, Lia Eden was the leader of a group named Salamullah which means perennial religion. Lia believed that she was the incarnation of the Angel Gabriel who delivers messages from God. She further declared that her son was the new prophet. In 1997, the Indonesian Ulamas Council (MUI) the Muslim council producing Islamic authorized opinions (edicts) declared that the Angel Gabriel would not return after the era of Prophet Muhammad, thus, Salamullah was considered to be deviating from religion because it was false and she was misleading Islam (Bruce, 2018). Lia Eden, in 2006, was charged with blasphemy under Article 156 (a) of the Indonesian Criminal Code for her conduct of claiming that she was the incarnation of the Angel Gabriel and having misinterpreted several verses of Al-Qur'an. The Court decided that Lia was guilty of abusing religion, in particular, Islam. She served two years in prison. In 2009, Lia Eden was found guilty again with religious blasphemy and was charged for two and a half years imprisonment after continuing her Salamullah group, as her conduct was threatening the harmony of the religious devout (Siregar \& Lubis, 2021).

Tajul Muluk is a Shi'a Muslim religious leader who organized a boarding school in Sampang, Madura, East Java. Shi'a Muslims were not a majority in his neighbourhood. In 2006, the Sunni Muslims, the majority group of Muslim began to claim that the Shi'a teaching was deviant and misleading because, in one of his teachings, Tajul Muluk made a statement claiming that Al-Qur'an which the Muslims used today was not the original text. In 2012, the Indonesian Ulamas Council (MUI) declared that Tajul Muluk's teaching of Shi'a was deviant and misleading. Accordingly, Tajul 
Muluk was able to be charged with blasphemy. Human rights activists claimed that they were told by the head of the East Java Police Force that initially, the police were reluctant to charge Tajul Muluk but proceeded after facing pressure from the Sampang District Head (Bourchier, 2019). Indeed, blasphemy provision in Indonesia was still not explicit in regard to the actus reus. There is no further explanation of what precisely are the objective elements of blasphemy. Later, Tajul Muluk was found guilty of blasphemy under article 156 (a) of the Indonesian Criminal Code by conducting deviant religion and was sentenced to two years imprisonment. Further, Tajul Muluk appealed his case to the East Java District Court, but he received a longer sentence of four years imprisonment. Tajul Muluk was one of the applicants of judicial review of blasphemy to the Indonesian Constitutional Court in 2010 (Crouch, 2012).

Basuki Tjahaja Purnama (Ahok) was Jakarta's Christian governor. On $27^{\text {th }}$ September 2016, he made a statement regarding the upcoming Jakarta regional election 2017 (Pilkada) and cited the AlMaidah verse 51 from Al-Qur'an during his official visit to Pramuka Island, Jakarta. He stated that people were often misled by religious leaders who use that verse to justify that Muslims should not have non-Muslims leaders. Indeed, the hardline Muslims group often used this verse not to choose a non-Muslim leader (J. Fenton, 2016). Ahok's statement led to some reactions and controversies, especially for the Muslims. It became worse after Buni Yani uploaded Ahok's statement to social media with a transcript and took off some words to stimulate the anger of the Muslims (Huda, 2019).

A couple of days after the video went viral, the hardline Muslim group, 'Islamic Defenders Front' or FPI organized a big march calling for Ahok's arrest for blasphemy. Furthermore, the FPI also seized the political agenda, pushing a message of intolerance in a Muslim-dominated country by saying not to vote him as governor in the upcoming Jakarta regional election because he was not a Muslim and came from a Chinese tribe (Philip \& Soumyaja, 2019). He was later charged with blasphemy under Article 156 (a) of the Indonesian Criminal Code. In his objection statement, Ahok stated that he did not intend to interpret the Al-Quran verse or blaspheme Islam wrongly. Ahok was sentenced to two years imprisonment for blasphemy which offended Muslims and broke the social harmony of the society (Dutta et al., 2019).

Overall, from those cases, it can be concluded that the judges in blasphemy cases have applied blasphemy articles in very different ways. Firstly, blasphemy articles are mostly applied to actions that should be protected by the freedom of expression and freedom of religion guaranteed by the Indonesian Constitution. Secondly, in most cases, there is a lack of mens rea or intention to commit blasphemy. For example in Arswendo's case, he did not have any intention to insult Islam (Telle, 2018). He only presented the result of the questionnaires. Thirdly, in blasphemy articles, there is no requirement of the element of a threat to public order. The Indonesian Constitution has already stated that the freedom of expression and religion may only be restricted to prevent any problems concerning morality, public order, and security. Moreover, blasphemy articles are located under Chapter $\mathrm{V}$ of the Indonesian Criminal Code on crimes against the public order. However, in the definition of blasphemy, there is no 'threat to public order' element. Therefore, Indonesian blasphemy law does not have any legal certainty because there is no further explanation of the definition and elements of blasphemy itself and thus cannot be predicted (Fossati et al., 2020).

\subsection{Blasphemy Law in Ireland}

Ireland is one of the countries in Europe which still has a blasphemy law. The blasphemy law has existed in Ireland in its Constitution and further in a specific law, the Defamation Act 1961 and the latest, the Defamation Act 2009. Even though Ireland is becoming more secular, multicultural, and multi-religious nowadays, historically, it remains a religious country (Scheim et al., 2020). This can be shown from the preface of its Constitution which refers to the Holy Trinity. In protecting the religion in Ireland, blasphemy is prohibited based on Article 40 (6) of the Irish Constitution: "the publication or utterance of the blasphemous, seditious, or indecent matter is an offence which shall be punishable in accordance with the law". Interestingly, the prohibition of blasphemy is placed in the same article with the freedom of expression guaranteed by the Irish Constitution. Indeed, the Irish Government aims to make blasphemous publications and speeches an exemption of the freedom of expression. Therefore, the provision claimed that the freedom of expression in Ireland is limited (Cox, 2020). 
However, the Irish Constitution does not give any precise definition of what blasphemy is. Indeed, as a constitutional offence, a criminal provision has to be sufficiently clear and defined. Thus the people may regulate their behavior accordingly. The Defamation Act 1961 recognizes and criminalizes blasphemous publications or speeches, but it does not cover the definition nor the elements of blasphemy. Ireland's Government follows the English common law for the definition of blasphemous libel (Ataullahjan et al., 2019).

The most famous blasphemy case in Ireland is Corway v. Independent Newspapers Ltd (1999). This case is initially a prosecution against a newspaper for publishing a blasphemous cartoon of priests and the Eucharist. However, the High Court (here in after, the Court) refused the case to go further to the prosecution. Then, the case was brought to the Irish Supreme Court. In this case, the Supreme Court agreed with the Court that blasphemy law could not be applied in the case because there was an absence of a legal definition of blasphemy. With the lack of a legal definition, actus reus and mens rea of blasphemy, there is no legal certainty to prosecute someone for blasphemy, especially when the Constitution also guarantees the freedom of religion and expression of all citizens.

As a consequence, blasphemy was urged to be removed from Irish law or to be more clearly defined in order to have more certainty. Surprisingly, the Irish government decided to reform its blasphemy law. It claimed that blasphemy law is still needed, as, in the past, the government have failed to define blasphemy precisely. Indeed, a precise definition of blasphemy law is needed for the law to have more legal certainty. The legislators follow the Court's recommendations while reforming the blasphemy law to have a more precise explanation of the definition, the actus reus and the mens rea; and more protection of all religions and faiths instead of only one specific religion. The legal certainty of blasphemy law in Ireland can be ensured. Eventually, Irish government passed a new blasphemy law, the Defamation Act of 2009 (Triwanto \& Aryani, 2020).

Article 36 of the Defamation Act of 2009 shows the definition, the actus reus and the mens rea of blasphemous matter. This article also shows that the current Irish blasphemy law protects any religions and faiths in Ireland, not only one particular religion. Article 36 (1) presents the definition and the elements of blasphemy for which someone can be prosecuted. The article defines blasphemy as "publishes or utters matter that is grossly abusive or insulting in relation to matters held sacred by any religion, thereby causing outrage among a substantial number of the adherents of that religion". However, there are still no further explanations about the elements of this article, for example, the clarifications of what and to what extent 'grossly abusive', 'matters held sacred', or 'substantial number of adherents' are (Christianto, 2020).

Despite these issues, that does not mean that the new blasphemy law is not providing legal certainty for Irish people. Legal certainty does not mean that everything should be exactly clear otherwise a law becomes too limited and narrow. Despite this, the Irish legislators have clearly distinguished what is considered as blasphemy and what is not. The new Irish blasphemy law now includes the criminal intent or the mens rea as part of the offence. It is listed in Article 36 (1) which means that to be prosecuted, someone should consciously perform blasphemous conduct (Fuad, 2019).

Thus, someone that has no intention of being blasphemous should be left out of the prosecution. Furthermore, there is also an exception of expression that cannot be prosecuted for blasphemy. It is regulated in Article 36 (3) that if someone can prove that the expression is an expression of artistic, political, scientific, or academic value, the person must be excluded from blasphemous conduct although it satisfies the definition of blasphemy. Indeed, this provision enhances the freedom of expression that the Irish Constitution guarantees. Overall, the Irish government reformed its blasphemy law in order to have more legal certainty by clearly explaining the definition and elements of blasphemy (Crouch, 2012).

\subsection{Blasphemy Law in Canada}

Canada is one of the countries in the world which still has blasphemy in their legislation. Blasphemy provision in Canada has never really changed since its introduction in the 1802 Canadian Criminal Code. Until today, blasphemy regulation has been in the Canadian Criminal Code. Canada is a multicultural country meaning that it respects all ethnicities, cultures, and religious groups living in Canada (Crouch, 2012). The Canadian Charter of Rights and Freedom (here in after, the Charter) guarantees the fundamental freedoms of everyone which include freedom of conscience and religion, 
freedom of thought, belief, opinion and expression, freedom of peaceful assembly, and freedom of association (Section 2 of the Charter).

Moreover, in the Multiculturalism Act of Canada, the government guarantees that people have the right to enjoy their cultures, practices their religion, and use their language. Therefore, to avoid any conflict in the society as a result of its multicultural characteristics, especially regarding religion, the government generates the prohibition on blasphemy (Singh \& McKleroy, 2011). Indeed, some believe that the blasphemy law contradicts the Section 2 of the Charter. However, in Section 1 of the Charter, it allows "such reasonable limits prescribed by law as can be demonstrably justified in a free and democratic society" (Singh \& McKleroy, 2011). Blasphemy law in Canada was first developed in Canada's original Criminal Code of 1892. Generally, the form of blasphemy provision in the current criminal code is substantially the same as the previous Criminal Code of 1802. Borrowing from the English common law offences term, Canada also uses the term 'blasphemous libels' in its Criminal Code. However, it did not import the definition from the English common law (Chrisendo et al., 2020).

During its journey, blasphemy law in Canada has also been challenged to be repealed. However, it was never successful. A prohibition of blasphemy is seen as a middle position which allows the truths from the religions to be open for debate and criticism with respect as a cultural identity (Nam et al., 2021). Thus, debate and criticism of religions are permitted as long as there is respect and no disturbing of the public order. Currently, Canada criminalizes blasphemous libel under Article 296 of the Canadian Criminal Code.

1. Everyone who publishes a blasphemous libel is guilty of an indictable offence and liable to imprisonment for a term not exceeding two years.

2. It is a question of fact whether or not any matter that is published is a blasphemous libel.

3. No person shall be convicted of an offence under this section for expressing in good faith and in decent language or attempting to establish by argument used in good faith and conveyed in decent language, an opinion on a religious subject.

Since its first implementation, blasphemy law in Canada has only slightly changed with the penalty being increased from one-year maximum imprisonment to two years maximum imprisonment. Regarding actus reus, it is prohibited to publish a blasphemous libel (Wylie et al., 2016). However, the definition of blasphemous libel is not available anywhere in Canadian legislation. Article 296 of the Canadian Criminal Code stated that it would be a question of fact to determine a blasphemous libel. It means that what is considered as blasphemy in Canada must be resolved by the jury at trial. Since the law has been enacted, there have been five prosecutions for blasphemy, in 1901, 1925, 1926, 1933, and 1936 namely Pelletier, Kinler, Sterry, St. Martin, and Rahard, respectively (Richardson et al., 2020).

Unfortunately, since the first until the last prosecution of blasphemy in Canada, there is no further clarification of what blasphemous libel is. It depends on the jury on a case-by-case basis to determine whether something is a blasphemous libel or not. By doing so, the legal certainty of blasphemy law in Canada is based on the precedence (Ataullahjan et al., 2019). Regarding the religion that the Canadian blasphemy law protected, of five cases, four cases were directed at blasphemy to Roman Catholic churches and one case to a Protestant church. Thus, blasphemy in Canada not only protects one religion like in English common law offence but instead protects all religions from being insulted. Furthermore, the blasphemy provision in Canada is indeed not explicitly limited to protect Christianity, but also other religions like Judaism or Islam (Fossati et al., 2020). Regarding mens rea or the guilty intention of blasphemy, there is a difference in the case law. Some case laws consider blasphemy as a strict liability offence (for example, Rahard) and others consider that the jury must find the intent of the defendant blaspheme (for example, Sterry and St. Martin). However, since the case of R. v. Prue (1999), the offences in the Criminal Code must be taken to import mens rea. Therefore, since blasphemous libel is in the Canadian Criminal Code, the element of mens rea or guilty intention to commit blasphemy must be taken into account. As stated in Article 296, blasphemy in Canada has a limitation. This article limits the government to interpret blasphemy in Canada (Bogdanova, 2018).

People who express their opinion regarding 'religious subjects' with 'good faith' and 'decent language' should not be prosecuted for blasphemy. Religious subjects do not only refer to God but 
also include all people or sacred objects in religions (Sineath et al., 2016). Fiss \& Kestenbaum specified 'good faith' as mens rea. Therefore, if people have good intentions while expressing their opinion even though it can be considered as blasphemy, they cannot be prosecuted. However, there are no further explanations regarding the extent to which an opinion is required to have 'good faith' and be in 'decent language' (Abraham \& Rufaedah, 2014). Overall, even though there is no written legal definition of blasphemy, the legal certainty of Canadian blasphemy law can still be held. The use of question of facts, previous cases (precedence), and the limitation for the government to interpret blasphemy still can satisfy the content and the predictability of blasphemy law in Canada (Avgoustidis, 2013).

\section{Conclusion}

Based on the discussion shown, the blasphemy laws are heterogeneously written by the national legislation of Indonesia, Ireland, and Canada. In Indonesia, the legal protection of religion against blasphemy is deeply rooted, mainly due to the position of religion as a core constitutional value. However, the blasphemy provision still does not have strong legal certainty. The blasphemy article is a 'rubber article', an article in the legal provision which does not clearly set forth the boundary between actus reus and mens rea. The official explanation of blasphemy law is still too broad to set limitations. Therefore, there is no certainty in the content of the law. In practice, in cases of Tajul Muluk and Ahok, the enforcement of blasphemy law could decisively affected by structural, political, or external pressure through the threat of public riot by conservative groups. As a result, people may doubt what they can do or what they cannot do. Thus, the law cannot provide predictability of blasphemy in society. The law fails to give protection to the people in the society. Meanwhile, Irish blasphemy law has been changed in the past few years. Before, blasphemy provision was examined in the Supreme Court because of the lack of precise legal definition of blasphemy, limitation of religion protected, and the element of mens rea or intention. Now, Irish blasphemy law is more clear and includes the element of mens rea. Moreover, the new blasphemy law in Ireland aims to protect one religion and any religion in Ireland. Indeed, Irish legislators have clearly distinguished what is considered as blasphemy and what is not. Irish government clearly defines blasphemy law as a limitation of the freedom of expression subject to public order and morality. Canada does not regulate its blasphemy law very strictly. As a common law country, it is a question of fact whether or not something can be considered blasphemy. From a civil law perspective, this may undermine legal certainty. However, Canada used precedence to keep its certainty and predictability. Even though the law does not define blasphemy precisely, Canada protects all religions from blasphemy.

\section{References}

Abraham, J., \& Rufaedah, A. (2014). "Theologization" of psychology and "psychologization" of religion: How do psychology and religion supposedly contribute to prevent and overcome social conflicts? Procedia Environmental Sciences, 20, 516-525. https://doi.org/10.1016/j.proenv.2014.03.064

Ataullahjan, A., Mumtaz, Z., \& Vallianatos, H. (2019). Family planning, Islam and sin: Understandings of moral actions in Khyber Pakhtunkhwa, Pakistan. Social Science \& Medicine, 230, 49-56. https://doi.org/10.1016/j.socscimed.2019.03.011

Avgoustidis, A. G. (2013). Obsessions from the past: A study of the chapter on "blasphemous thoughts" in "The Ladder of Divine Ascent" (7th century AD). Asian Journal of Psychiatry, 6(6), 595-598. https://doi.org/10.1016/j.ajp.2013.08.072

Bogdanova, E. (2018). Obtaining redress for abuse of office in Russia: The Soviet legacy and the long road to administrative justice. Communist and Post-Communist Studies, 51(3), 273-284. https://doi.org/10.1016/j.postcomstud.2018.07.002

Bourchier, D. M. (2019). Two decades of ideological contestation in Indonesia: From democratic cosmopolitanism to religious nationalism. Journal of Contemporary Asia, 1-21. https://doi.org/10.1080/00472336.2019.1590620 
Bruce, T. (2018). New technologies, continuing ideologies: Online reader comments as a support for media perspectives of minority religions. Discourse, Context \& Media, 24, 53-75. https://doi.org/10.1016/j.dcm.2017.10.001

Castillo-Manzano, J. I., Castro-Nuño, M., López-Valpuesta, L., \& Pedregal, D. J. (2019). From legislation to compliance: The power of traffic law enforcement for the case study of Spain. Transport Policy, 75, 1-9. https://doi.org/10.1016/j.tranpol.2018.12.009

Chrisendo, D., Krishna, V. V., Siregar, H., \& Qaim, M. (2020). Land-use change, nutrition, and gender roles in Indonesian farm households. Forest Policy and Economics, 118, 102245. https://doi.org/10.1016/j.forpol.2020.102245

Christianto, H. (2020). Measuring cyber pornography based on Indonesian living law: A study of current law finding method. International Journal of Law, Crime and Justice, 60, 100348. https://doi.org/10.1016/j.ijlcj.2019.100348

Cox, N. (2019). Stephen Fry, the meaning of life, and the problem with Irish blasphemy law. Oxford Journal of Law and Religion, 8(2), 247-269. https://doi.org/10.1093/ojlr/rwz019

Cox, N. (2020). Justifying blasphemy laws: Freedom of expression, public morals, and international human rights law. Journal of Law and Religion, 35(1), 33-60. https://doi.org/10.1017/jlr.2020.11

Crouch, M. A. (2012). Law and religion in Indonesia: The constitutional court and the blasphemy law. Asian Journal of Comparative Law, 7(1), 1-46. https://doi.org/10.1515/1932-0205.1391

De Clercq, D., Haq, I. U., \& Azeem, M. U. (2017). Perceived threats of terrorism and job performance: The roles of job-related anxiety and religiousness. Journal of Business Research, 78, 23-32. https://doi.org/10.1016/j.jbusres.2017.04.013

Doomen, J. (2021). Blasphemy in an age of corroding secularity. Law and Critique, 32(1), 51-67. https://doi.org/10.1007/s10978-020-09268-6

Dutta, S., Khan, S., \& Lorway, R. (2019). Following the divine: an ethnographic study of structural violence among transgender jogappas in South India. Culture, Health \& Sexuality, 21(11), 12401256. https://doi.org/10.1080/13691058.2018.1555718

Eskin, M., Baydar, N., El-Nayal, M., Asad, N., Noor, I. M., Rezaeian, M., Abdel-Khalek, A. M., Al Buhairan, F., Harlak, H., Hamdan, M., Mechri, A., Isayeva, U., Khader, Y., Khan, A., Al Sayyari, A., Khader, A., Behzadi, B., Öztürk, C. Ş., Agha, H., ... Khan, M. M. (2020). Associations of religiosity, attitudes towards suicide and religious coping with suicidal ideation and suicide attempts in 11 muslim countries. Social Science \& Medicine, 265, 113390. https://doi.org/10.1016/j.socscimed.2020.113390

Faiz, P. M. (2016). The protection of civil and political rights by the constitutional court of Indonesia. Indonesia Law Review, 6(2), 158. https://doi.org/10.15742/ilrev.v6n2.230

Fossati, D., Aspinall, E., Muhtadi, B., \& Warburton, E. (2020). Ideological representation in clientelistic democracies: The Indonesian case. Electoral Studies, 63, 10211. https://doi.org/10.1016/j.electstud.2019.102111

Fuad, C. (2019). The curious case of the blasphemer: Ambiguity as literary device in leviticus 24:1023. Horizons in Biblical Theology, 41(1), 51-70. https://doi.org/10.1163/18712207-12341385

Hasan, N. (2017). Religious diversity and blasphemy law: Understanding growing religious conflict and intolerance in post-Suharto Indonesia. Al-Jami 'ah: Journal of Islamic Studies, 55(1), 105126. https://doi.org/10.14421/ajis.2017.551.105-126

Huda, M. S. (2019). The local construction of religious blasphemy in East Java. Journal of Indonesian Islam, 13(1), 96-114. https://doi.org/10.15642/JIIS.2019.13.1.96-114

J. Fenton, A. (2016). Faith, intolerance, violance and bigotry: Legal and constitutional issues of freedom of religion in Indonesia. Journal of Islamic Studies, 10(2), 181. https://doi.org/10.15642/JIIS.2016.10.2.181-212 
Marshall, P. (2018). The ambiguities of religious freedom in Indonesia. The review of faith \& international affairs, 16(1), 85-96. https://doi.org/10.1080/15570274.2018.1433588

Moeis, F. R., Dartanto, T., Moeis, J. P., \& Ikhsan, M. (2020). A longitudinal study of agriculture households in Indonesia: The effect of land and labor mobility on welfare and poverty dynamics. World Development Perspectives, 20, 100261. https://doi.org/10.1016/j.wdp.2020.100261

Nam, P. P., Thanh Huyen, P. T., \& Van Ha, P. (2021). Factors affecting the management of public agricultural land fund in Gia Lam District, Hanoi City, Vietnam. Land Use Policy, 101, 105151. https://doi.org/10.1016/j.landusepol.2020.105151

Necula, M. I. (2014). Aspects concerning the penal protection of the freedom of religious beliefs. Procedia - Social and Behavioral Sciences, 149, 639-646. https://doi.org/10.1016/j.sbspro.2014.08.241

Philip, J., \& Soumyaja, D. (2019). Workplace diversity and inclusion: policies and best practices for organisations employing transgender people in India. International Journal of Public Policy, 15(3/4), 299. https://doi.org/10.1504/IJPP.2019.103011

Rehman, J., \& Shahid, A. (2018). The Asian Yearbook of Human Rights and Humanitarian Law. Brill | Nijhoff. https://doi.org/10.1163/9789004346888

Richardson, P., Pihlaja, S., Nagashima, M., Wada, M., Watanabe, M., \& Kheovichai, B. (2020). Blasphemy and persecution: Positioning in an inter-religious discussion. Text \& Talk, 40(1), 7598. https://doi.org/10.1515/text-2019-2049

Rosidah, Z. N. (2020). Coherence of the rules of sharia against Pancasila. Bestuur, 8(1), 40. https://doi.org/10.20961/bestuur.v8i1.42723

Saud, M. (2020). Civic engagement, youth socialisation and participation in public spheres in Indonesia. Children and Youth Services Review, 119, 105669. https://doi.org/10.1016/j.childyouth.2020.105669

Scheim, A. I., Perez-Brumer, A. G., \& Bauer, G. R. (2020). Gender-concordant identity documents and mental health among transgender adults in the USA: a cross-sectional study. The Lancet Public Health, 5(4), e196-e203. https://doi.org/10.1016/S2468-2667(20)30032-3

Sholehudin, M. (2020). Politik Hukum Penistaan Agama Perspektif Rudolf Stammler. Legality: Jurnal Ilmiah Hukum, 28(1), 96-106. https://doi.org/10.22219/1jih.v28i1.11355

Sineath, R. C., Woodyatt, C., Sanchez, T., Giammattei, S., Gillespie, T., Hunkeler, E., Owen-Smith, A., Quinn, V. P., Roblin, D., Stephenson, R., Sullivan, P. S., Tangpricha, V., \& Goodman, M. (2016). Determinants of and barriers to hormonal and surgical treatment receipt among transgender people. Transgender Health, 1(1), 129-136. https://doi.org/10.1089/trgh.2016.0013

Singh, A. A., \& McKleroy, V. S. (2011). "Just getting out of bed is a revolutionary act": The resilience of transgender people of color who have survived traumatic life events. Traumatology, 17(2), 34-44. https://doi.org/10.1177/1534765610369261

Siregar, G. T. ., \& Lubis, M. R. (2021). Juridical analysis of religious blasphemy crimes through smartphone applications based on the information and electronic transactions (ite). Journal of Contemporary Issues in Business and Government, 27(02), 1006-1012. https://doi.org/10.47750/cibg.2021.27.02.120

Telle, K. (2018). Faith on Trial: Blasphemy and 'Lawfare' in Indonesia. Ethnos, 83(2), 371-391. https://doi.org/10.1080/00141844.2017.1282973

Tømte, A. (2012). Constitutional Review of the Indonesian Blasphemy Law. Nordic Journal of Human Rights, 30(2), 174-204. https://doi.org/10.18261/ISSN1891-814X-2012-02-04 ER

Triwanto, T., \& Aryani, E. (2020). The urgency of granting authority to assess corruption justice collaborators. Bestuur, 8(1), 60-69. https://doi.org/10.20961/bestuur.v8i1.42720

Tyson, A. (2021). Blasphemy and judicial legitimacy in Indonesia. Politics and Religion, 14(1), 182205. https://doi.org/10.1017/S1755048319000427 
Winter, S., Diamond, M., Green, J., Karasic, D., Reed, T., Whittle, S., \& Wylie, K. (2016). Transgender people: health at the margins of society. The Lancet, 388(10042), 390-400. https://doi.org/10.1016/S0140-6736(16)00683-8

Wylie, K., Knudson, G., Khan, S. I., Bonierbale, M., Watanyusakul, S., \& Baral, S. (2016). Serving transgender people: Clinical care considerations and service delivery models in transgender health. The Lancet, 388(10042), 401-411. https://doi.org/10.1016/S0140-6736(16)00682-6 